\title{
Melatonin diminishes oxidative stress in plasma, retains erythrocyte resistance and restores white blood cell count after low-dose lipopolysaccharide exposure in mice
}

\author{
Natalia Kurhaluk ${ }^{1}$, Olga V. Zaitseva ${ }^{2}$, Alina Sliuta ${ }^{3}$, Svitlana Kyriienko ${ }^{3}$ and Pawel \\ J. Winklewski ${ }^{4,5}$ \\ ${ }^{1}$ Department of Zoology and Animal Physiology, Institute of Biology and Environment Protection, Pomeranian University \\ of Slupsk, Slupsk, Poland \\ 2 Palladin Institute of Biochemistry, National Academy of Sciences of Ukraine, Kyiv, Ukraine \\ ${ }^{3}$ Department of Ecology and Nature Protection, National State University of Chernihiv, Chernihiv, Ukraine \\ ${ }^{4}$ Department of Human Physiology, Faculty of Health Sciences, Medical University of Gdansk, Gdansk, Poland \\ ${ }^{5}$ Department of Clinical Anatomy and Physiology, Faculty of Health Sciences, Pomeranian University of Slupsk, Slupsk, \\ Poland
}

\begin{abstract}
The aim of the study was to elucidate the effects of melatonin administration $(10 \mathrm{mg} / \mathrm{kg}$, 10 days) in a model of inflammation and oxidative stress induced by low-dose bacterial lipopolysaccharide (LPS, once $150 \mu \mathrm{g}$ ). Assays were carried out in quadruplicate in the control, melatonin (10 mg/ $\mathrm{kg}, 10$ days), acute LPS administration (once $150 \mu \mathrm{g}$ ) and LPS plus melatonin groups. Blood morphological examination was performed. Erythrocyte resistance to haemolytic agents, ceruloplasmin, diene conjugates, malondialdehyde, oxidatively modified protein concentrations, total antioxidant capacity and antioxidant enzyme activity in plasma were measured. LPS administration in mice resulted in white blood cell (WBC) depletion, erythrocyte cell membrane impairment and oxidative stress in plasma characterised by lipid and protein oxidative processes, decreased antioxidative defence and augmented ceruloplasmin concentrations. Melatonin treatment provided to LPS-exposed animals restored WBC counts, ameliorated erythrocyte membrane damage and decreased overall oxidative stress in plasma. Melatonin provides multilevel protection in animals exposed to low-dose LPS.
\end{abstract}

Key words: Melatonin — LPS - Oxidative stress - Lipids oxygenation - Oxidatively modified proteins - Antioxidant enzymes - Ceruloplasmin - Blood - Plasma

\section{Introduction}

Systemic inflammation is one way in which an organism can respond to a bacterial infection (Faist et al. 1999). Gram-negative bacteria lipopolysaccharide (LPS) is the most thoroughly studied inducer of such an inflammatory response (Annane et al. 2005; Wang and Quinn 2010). LPS exposure results in the development of various types of endotoxic shock, depending on dose (Cadenas and Cadenas

Correspondence to: Pawel Winklewski, Department of Human Physiology, Medical University of Gdansk, Tuwima Str. 15, 80-210 Gdansk, Poland

E-mail: pawelwinklewski@wp.pl
2002). The complexity of pathological changes caused by LPS is the consequence of two interrelated processes. The first is related to the direct toxic effect of LPS on vital organs and functions, and the second is associated with the development of excessive protective reactions of the organism (Dauphinee and Karsan 2006). The clinical consequences of lipopolysaccharide endotoxin, such as sepsis and septic shock, are among the most frequent causes of patient death (Wichmann et al. 2000).

Recently, risks associated with subclinical endotoxaemia and subsequent low grade inflammation and oxidative stress associated with obesity and diabetes mellitus have been increasingly recognized. Obesity and diabetes mellitus favour endotoxin (especially LPS) translocation across the intestinal 
barrier, leading to its mild increase in concentration in the bloodstream (Cani et al. 2008). In addition, hyperglycaemia, hyperinsulinemia and insulin resistance impair the functionality of polymorphonuclear neutrophils, Kupffer cells, and macrophages, suppressing the bactericidal activity of leukocytes (Yu et al. 2003; Creely et al. 2007). Therefore, diabetic subjects seem to have lower clearance of LPS and consequently, increased LPS concentrations. Finally, diabetic subjects are more susceptible to developing infections (Al-Attas et al. 2009). Serum LPS activity correlates with metabolic syndrome components, such as triglycerides and fasting glucose. Therefore, serum LPS activity combined with common metabolic abnormalities in diabetes mellitus may contribute to the development of macro- and micro-vascular complications (Lassenius et al. 2011).

The spectrum of physiological effects caused by melatonin is quite wide (Melchiorri et al. 1995; Escames et al. 1997; von Gall et al. 2002). The action of this substance is observed at the systemic, tissue, cellular and subcellular levels (Saravanan et al. 2007). This is due to the ability of melatonin to readily dissolve in water and lipids, thus it penetrates through cell membranes and initiates various physiological processes. Melatonin interacts with the membrane receptors $\mathrm{MT}_{1}$ and $\mathrm{MT}_{2}$, which are $\mathrm{G}$ protein-coupled receptors located in different parts of the central nervous system, the retina of the eye, blood vessels, the gastrointestinal tract, liver, kidneys, skin and immune cells; moreover, melatonin can bind to intracellular proteins such as calmodulin and tubulin (Escames et al. 1997; von Gall et al. 2002). Melatonin reduces both basal and bacterial LPS-induced lipid peroxidation in vitro, as was shown by Sewerynek et al. (1995). Pretreatment with melatonin significantly increases antioxidant activities and decreases lipoperoxidation and oxidative protein levels in selected tissues and blood. These results indicate that the significant protective activity of melatonin on oxidative stress and morphological blood parameters induced by LPS might be associated with the antioxidant activity of melatonin.

In our study, we aimed to determine using an in vivo experimental mice model, whether single low dose of LPS causes oxidative damage in the blood, and whether melatonin has a protective role on the haematological profile, the resistance of erythrocytes to haemolytic agents and overall oxidative stress in plasma. We hypothesised that melatonin would diminish LPS-induced oxidative injury.

\section{Materials and Methods}

\section{Animals and experimental design}

The experiments were performed in accordance with the Guidelines of the European Union Council and the current laws in Ukraine, and approved by the Ethical Commission of National State University in Chernihiv (2612/2016). All experiments were performed between 10:00 a.m. and 12:00 p.m. to compensate for the circadian rhythm. Healthy male white Balb/c mice (Mus musculus), weighing about 20-30 g and aged about 2-3 months, were used in the experiments. The data were collected from 24 adult animals divided into four groups. The mice were housed at a constant temperature of $20 \pm 2{ }^{\circ} \mathrm{C}$. The animals had free access to food and water throughout the experiments.

\section{Experimental groups}

The mice were randomly assigned into four groups: untreated controls $(n=6)$, melatonin-treated $(n=6)$, LPS-treated $(n=6)$ and LPS+melatonin-treated $(n=6)$. Melatonin was given as a daily intraperitoneal injection at a dose of $10 \mathrm{mg} /$ $\mathrm{kg}$ melatonin for 10 days. Melatonin was dissolved in a minimum volume of ethanol and diluted in $0.9 \% \mathrm{NaCl}$ to yield a dose of $10 \mathrm{mg} / \mathrm{kg}$ body weight, as described in previous studies (Bonnefont-Rousselot and Collin 2010; Kurhaluk et al. 2017). LPS (E. coli serotype 026:B6, Sigma-Aldrich Sp. z.o.o, Poznan, Poland) was injected once intraperitoneally in a $150 \mu \mathrm{g}$ dose per mouse, as described by Yang et al. (2013) and Blanque et al. (1999). Control mice were given 0.9\% $\mathrm{NaCl}$ intraperitoneally.

\section{Drugs and solutions}

EDTA, HEPES, $\mathrm{KCl}, \mathrm{K}_{2} \mathrm{CO}_{3}, \mathrm{KH}_{2} \mathrm{PO}_{4}$, EDTA, 2-thiobarbituric acid were purchased from Sigma-Aldrich (SigmaAldrich Sp. z.o.o, Poznan, Poland). All drugs were freshly prepared. All other used reagents were of analytical reagent grade.

\section{Sampling}

Blood samples ( $3 \mathrm{ml}$ ) were collected from single mouse into tubes containing $\mathrm{K}_{2}$ EDTA. After centrifugation, plasma samples were removed and frozen at $-20^{\circ} \mathrm{C}$ and stored until analysis.

\section{Isolation of erythrocytes}

Blood samples were taken from the caudal vein using syringes in less than $1 \mathrm{~min}$ and transferred to tubes containing EDTA, then kept on ice until centrifugation at 3,000 $\times g$ for $10 \mathrm{~min}$. The plasma was removed; the erythrocytes were washed three times with five volumes of saline solution and centrifuged at 3,000 $\times g$ for $10 \mathrm{~min}$. Haemolysed erythrocytes were used for the determination of osmotic and acid resistance, and plasma was used for the determination 2-thiobarbituric acid reactive substances. 


\section{Resistance of erythrocytes to haemolytic reagents}

\section{Acid resistance of erythrocytes}

The acid resistance of erythrocytes was determined according to the method of Terskov and Gitelson (1957). The method is based on the measurement of erythrocyte dynamic disintegration in $0.1 \mathrm{~N} \mathrm{HCl}$ used as the haemolytic reagent. Briefly, the duration of $\mathrm{HCl}$ action serves as a measure of erythrocyte resistance. Freshly collected blood samples were centrifuged at 3,000 rpm for 10 minutes. The absorbance was read at $540 \mathrm{~nm}$ every $30 \mathrm{~s}$ after the addition of $\mathrm{HCl}$ until the end of haemolysis. Differences in absorbance at the beginning (taken as 100\%) and at the end of haemolysis were determined. The acid resistance of erythrocytes as a $\%$ of the disintegration of erythrocytes for every period of time was expressed as a curve.

\section{Osmotic resistance of erythrocytes}

The Kamyshnikov (2004) method was used to assay the osmotic resistance of erythrocytes. The method is based on the measurement of differences between the osmotic resistance of erythrocytes in a mixture containing different concentrations of sodium chloride and urea. The absorbance of the mixture containing erythrocytes and $0.3 \mathrm{~mol} / \mathrm{l}$ urea was determined as $100 \%$. The degree of haemolysis in every test tube was measured spectrophotometrically at a wavelength of $540 \mathrm{~nm}$. The haemolysis of erythrocytes (\%) in test tubes with different urea concentrations was expressed as a curve.

\section{Haematological profile}

$\mathrm{K}_{2}$ EDTA-treated blood was collected and analysed in an automated manner (Abacus Junior Vet, Austria) considering the following parameters: red blood cell count $\left(\mathrm{RBC}, 10^{6} / \mu \mathrm{l}\right)$, white blood cell (WBC, $\left.10^{3} / \mu \mathrm{l}\right)$, lymphocytes $\left(10^{3} / \mu \mathrm{l}\right)$, monocytes $\left(10^{3} / \mu \mathrm{l}\right)$, neutrophils $\left(10^{3} / \mu \mathrm{l}\right)$, lymphocytes $(\%)$, monocytes (\%) and neutrophils (\%), haemoglobin $(\mathrm{Hb}, \mathrm{dl} / \mathrm{g})$, packed cell volume (PCV), haematocrit (HCT, \%), mean corpuscular volume (MCV, fl), mean corpuscular haemoglobin $(\mathrm{MCH}, \mathrm{pg})$, mean corpuscular haemoglobin concentration ( $\mathrm{MCHC}, \mathrm{g} / \mathrm{dl})$, RBC distribution width (RDWc, \%), platelet count (PLT, 10 3 / $\mu \mathrm{l})$, packed cell volume (PCV, \%), mean platelet volume (MPV, fl) and platelet distribution width (PDWc, \%).

\section{Biochemical assays}

\section{Conjugated dienes assay}

The level of conjugated dienes was determined according to Kamyshnikov (2004) method. Conjugated dienes groups were determined at absorption peak at the wavelength of $233 \mathrm{~nm}$ and expressed in nmol per miligram of protein.

\section{Thiobarbituric acid reactive substances (TBARS) assay}

TBARS were estimated using the method of Kamyshnikov (2004). TBARS levels were expressed in $\mu \mathrm{mol}$ of malondialdehyde (MDA) per mililitre of plasma.

\section{Protein carbonyl derivatives assay}

The oxidatively modified protein (OMP) rate was estimated using the reaction detecting carbonyl derivatives of amino acids with 2,4-dinitrophenyl hydrazine (DNFH) as described by Levine et al. (1990) and modified by Dubinina et al. (1995). The final solution was centrifuged to remove any insoluble material. The carbonyl content was calculated from the absorbance measurement at $370 \mathrm{~nm}$ and $430 \mathrm{~nm}$ and an absorption coefficient $22,000 \mathrm{M}^{-1} \cdot \mathrm{cm}^{-1}$. Carbonyl groups were determined spectrophotometrically at $370 \mathrm{~nm}$ (aldehyde derivatives (AD), $\mathrm{OMP}_{370}$ ) and $430 \mathrm{~nm}$ (ketone derivatives (KD), $\mathrm{OMP}_{430}$ ), and expressed in nmol per millilitre of blood.

\section{Superoxide dismutase activity assay}

Superoxide dismutase (SOD, E.C. 1.15.1.1) activity in the blood was determined according to Kostiuk et al. (1990). SOD activity was assessed by its ability to eliminate $\mathrm{O}_{2}{ }^{-}$during quercetin auto-oxidation in an alkaline medium $(\mathrm{pH}$ 10.0). Absorbance at $406 \mathrm{~nm}$ was measured immediately and after $20 \mathrm{~min}$. Activity is expressed in units of SOD per millilitre of blood.

\section{Catalase activity assay}

Catalase (CAT, E.C. 1.11.1.6) activity was determined by measuring the decrease in $\mathrm{H}_{2} \mathrm{O}_{2}$ in the reaction mixture using the method of Koroliuk et al. (1988). One unit of CAT activity is defined as the amount of enzyme required for the decomposition of $1 \mu \mathrm{mol} \mathrm{H}_{2} \mathrm{O}_{2}$ per minute per litre of plasma.

\section{Glutathione reductase activity assay}

Glutathione reductase (GR, E.C. 1.6.4.2) activity in the blood was measured according to the method of Glatzle et al. (1974). The enzymatic activity was assayed spectrophotometrically by measuring NADPH consumption. A blank without NADPH was used and the GR activity was expressed as nmol NADPH per minute per millilitre of blood. 


\section{Glutathione peroxidase activity assay}

Glutathione peroxidase (GPx, EC 1.11.1.9) activity was determined by the detection of non-enzymatic utilisation of reduced glutathione ( $\mathrm{GSH}$ ) as the reacting substrate at $412 \mathrm{~nm}$ after incubation with 5,5-dithiobis-2-nitrobenzoic acid (DTNB) according to the method of Moin (1986). GPx activity is expressed as nmol GSH per minute per millilitre of blood.

\section{Total antioxidant capacity (TAC) assay}

The TAC level in the plasma was estimated spectrophotometrically with Tween 80 oxidation at $532 \mathrm{~nm}$ by measuring the TBARS level following the method described by Galaktionova et al. (1998). Tissue inhibits $\mathrm{Fe}^{2+}$ /ascorbate-induced oxidation of Tween 80 resulting in a decrease of TBARS level. Absorbance of blank was determined as $100 \%$. The level of TAC in sample (\%) was calculated according to the absorbance of blank.

For the quantification of proteins, the Bradford method (1976) was used with bovine serum albumin as the standard. Absorbance was recorded at $595 \mathrm{~nm}$. All enzymatic assays were carried out at $22 \pm 0.5^{\circ} \mathrm{C}$ using a Specol 11 spectrophotometer (Carl Zeiss Jena, Germany) in duplicate.

\section{Statistical analysis}

Results are expressed as mean \pm SEM. All variables were tested for a normal distribution using the KolmogorovSmirnov and Lilliefors tests $(p>0.05)$ and the homogeneity of variance was checked using Levene's test. The significance of differences in the level of lipid peroxidation, amino acid carbonyl derivatives and antioxidant enzyme activities between the control and experimental groups was examined using one-way analysis of variance (ANOVA) and Bonferonni's post-hoc test. Statistical analysis was carried out on a double ways: the effect of melatonin and LPS was compared with those of the control group, and the combined effect of melatonin and LPS was compared with the data of the melatonin group and the LPS group separately. Differences were considered significant at $p<0.05$. In addition, the associations between the data from all individuals were evaluated using Pearson's correlation analysis. All statistical calculations were performed on separate data from each individual with Statistica 8.0 software (StatSoft Inc., Poland).

\section{Results}

The haematological data are presented in Table 1. Melatonin did not cause statistically significant changes in the blood cell

Table 1. Effects of melatonin, LPS and combined LPS plus melatonin administration on blood morphology in mice

\begin{tabular}{|c|c|c|c|c|}
\hline \multirow{2}{*}{$\begin{array}{l}\text { Morphological blood } \\
\text { parameters }\end{array}$} & \multicolumn{4}{|c|}{ Group } \\
\hline & Control & $\mathrm{Mel}$ & LPS & $\mathrm{LPS}+\mathrm{Mel}$ \\
\hline $\operatorname{RBC}\left(10^{6} / \mu \mathrm{l}\right)$ & $7.91 \pm 0.29$ & $7.18 \pm 0.44$ & $6.40 \pm 0.61$ & $7.42 \pm 0.18$ \\
\hline $\operatorname{WBC}\left(10^{3} / \mu \mathrm{l}\right)$ & $4.79 \pm 0.36$ & $5.93 \pm 0.83$ & $3.56 \pm 0.85$ & $6.93 \pm 0.67^{\mathrm{aa}, 2}$ \\
\hline $\operatorname{LYM}\left(10^{3} / \mu \mathrm{l}\right)$ & $3.60 \pm 0.23$ & $3.94 \pm 0.08$ & $2.64 \pm 0.58$ & $7.18 \pm 0.50^{\mathrm{aa}, 3}$ \\
\hline $\operatorname{MON}\left(10^{3} / \mu \mathrm{l}\right)$ & $0.18 \pm 0.04$ & $0.25 \pm 0.52$ & $0.17 \pm 0.09$ & $0.20 \pm 0.06$ \\
\hline $\operatorname{NEU}\left(10^{3} / \mu \mathrm{l}\right)$ & $1.01 \pm 2.26$ & $1.74 \pm 0.46$ & $0.75 \pm 0.20$ & $1.56 \pm 0.18^{\mathrm{aa}}$ \\
\hline $\operatorname{LYM}(\%)$ & $75.71 \pm 2.63$ & $66.38 \pm 4.86$ & $72.42 \pm 2.24$ & $74.98 \pm 2.71$ \\
\hline MON (\%) & $3.70 \pm 0.61$ & $4.38 \pm 0.52$ & $3.78 \pm 1.19$ & $2.68 \pm 0.64$ \\
\hline NEU (\%) & $20.57 \pm 2.26$ & $29.22 \pm 5.27$ & $20.83 \pm 2.22$ & $22.32 \pm 2.72$ \\
\hline $\mathrm{Hb}(\mathrm{g} / \mathrm{dl})$ & $13.54 \pm 0.59$ & $12.45 \pm 0.55$ & $11.03 \pm 1.28$ & $12.67 \pm 0.59$ \\
\hline $\operatorname{HCT}(\%)$ & $42.70 \pm 1.86$ & $39.31 \pm 2.46$ & $35.52 \pm 3.43$ & $40.55 \pm 1.86$ \\
\hline MCV (fl) & $53.71 \pm 0.78$ & $54.83 \pm 0.65$ & $55.50 \pm 0.67$ & $54.50 \pm 0.76$ \\
\hline $\mathrm{MCH}(\mathrm{pg})$ & $17.07 \pm 0.20$ & $17.47 \pm 0.37$ & $17.03 \pm 0.53$ & $17.08 \pm 0.23$ \\
\hline $\mathrm{MCHC}(\mathrm{g} / \mathrm{dl})$ & $31.74 \pm 0.36$ & $31.93 \pm 0.68$ & $30.7 \pm 0.75$ & $31.28 \pm 0.40$ \\
\hline RDWc (\%) & $18.13 \pm 0.30$ & $18.0 \pm 0.17$ & $18.52 \pm 0.19$ & $17.72 \pm 0.21^{\mathrm{aa}, 4}$ \\
\hline $\operatorname{PLT}\left(10^{3} / \mu \mathrm{l}\right)$ & $598.43 \pm 39.53$ & $634.33 \pm 146.35$ & $536.17 \pm 38.32$ & $504.33 \pm 61.78$ \\
\hline PCT (\%) & $0.47 \pm 0.03$ & $0.49 \pm 0.11$ & $0.41 \pm 0.03$ & $0.38 \pm 0.04$ \\
\hline MPV (fl) & $7.81 \pm 0.05$ & $7.83 \pm 0.11$ & $7.57 \pm 0.11$ & $7.67 \pm 0.17$ \\
\hline PDWc (\%) & $30.91 \pm 0.15$ & $30.62 \pm 0.20$ & $29.52 \pm 0.26^{\mathrm{a}, 1}$ & $30.50 \pm 0.35$ \\
\hline
\end{tabular}

Results are expressed as mean \pm S.E.M. Differences between experimental groups were analysed by one-way ANOVA and Bonferoni post-hock test; $(n=6)$. Control, control animals; Mel, melatonin administration; LPS, LPS-induced toxicity; LPS+Mel, LPS-induced toxicity and melatonin administration. Significant differences between groups: ${ }^{\mathrm{a}} p<0.05 v s$. Control group, ${ }^{\text {aa }} p<0.05 v s$. LPS group; ${ }^{1} p=0.002,{ }^{2} p=0.022,{ }^{3} p=0.016,{ }^{4} p=0.024$. 


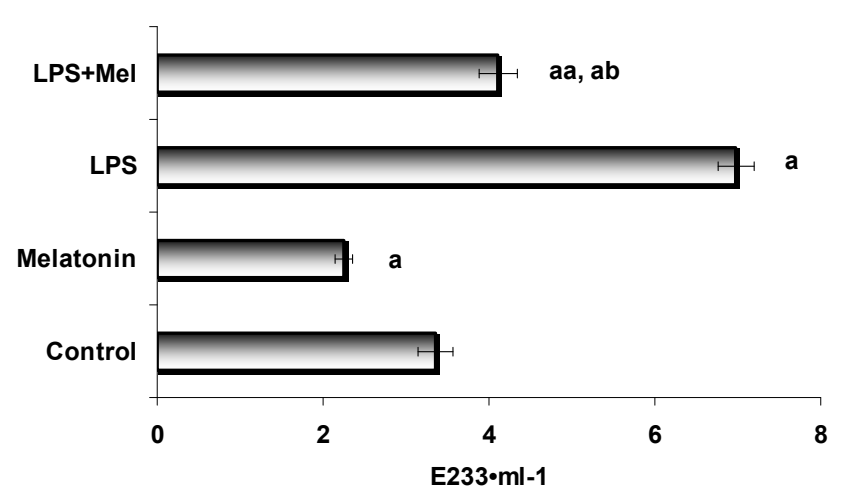

Figure 1. Effect of melatonin (Mel) on conjugated diene contents in plasma during LPS-induced toxicity $\left(\mathrm{E} 233 \cdot \mathrm{ml}^{-1}\right)$ in mice. Results are expressed as mean \pm S.E.M. Differences between experimental groups were analysed by one-way ANOVA and Bonferoni post-hock test; $(n=6)$. Control, control animals; Mel, melatonin administration; LPS, LPS-induced stress model, LPS+Mel, LPS-induced stress model and melatonin administration. Significant differences between groups: ${ }^{\mathrm{a}} p<0.05$ vs. Control group, ${ }^{\mathrm{a} a} p<0.05$ vs. LPS group, ${ }^{\mathrm{ab}} p<0.05$ vs. Mel group.

counts in mice. A single dose of LPS resulted in the depletion of WBC, mostly lymphocytes and neutrophils. Melatonin administration in LPS-exposed mice restored WBC counts compared to the LPS-treated group.

LPS administration was associated with the free radical oxidation of lipids. As this process occurs in several stages, we decided to assess the degree of change at the beginning and at the end of the lipoperoxidation process (LPO). Diene conjugation is considered to be a primary product following the formation of diene conjugates and ketodienes (Fig. 1). Consequently, we estimated the initial substrate accumulation in this stage of free radical oxidation in plasma. After LPS treatment, the concentration of conjugated dienes was significantly higher $(\mathrm{F}=16.94, p=0.000)$ compared to those observed in control mice. Melatonin statistically decreased

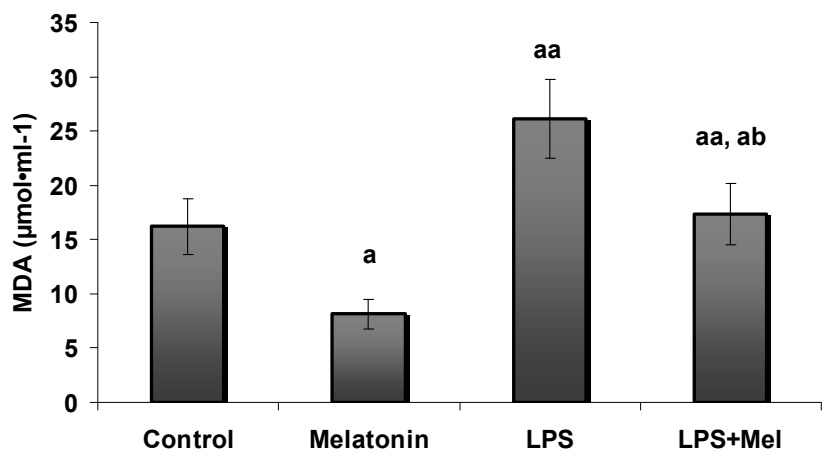

Figure 2. Effect of melatonin on LPS-induced lipid peroxide levels estimated as MDA value $\left(\mu \mathrm{mol} \mathrm{MDA} \cdot \mathrm{ml}^{-1}\right)$ in the plasma of mice. Results are expressed as mean \pm S.E.M. Differences between experimental groups were analysed by one-way ANOVA and Bonferoni post-hock test; $(n=6)$. Significant differences between groups: ${ }^{\mathrm{a}} p<$ 0.05 vs. Control group, ${ }^{\mathrm{aa}} p<0.05$ vs. LPS group. ${ }^{\mathrm{ab}} p<0.05$ vs. Mel group. For abbreviations see Figure 1.

the concentration of conjugated dienes in plasma compared to LPS-treated mice. The concentration of MDA (Fig. 2), i.e. the end product of the terminal stages of free radical oxidation of lipids plasma, was significantly higher in plasma in LPS-exposed mice compared to the control group ( $\mathrm{F}=$ $13.84, p=0.000)$. Melatonin treatment in LPS-exposed mice resulted in lower MDA concentrations.

In most cases, LPS toxicity is associated with intensive initial and terminal stages of LPO. Erythrocytes are one of the most sensitive indicators of increased ROS exposure. For this purpose, we carried out the determination of the acid resistance of erythrocytes to haemolytic reagents. The method shows the dynamics of erythrocyte disintegration, which is typically expressed as a curve. The acid resistance of erythrocytes (Fig. 3) was significantly higher after melatonin treatment compared to the response in erythrocytes from control mice. LPS significantly increased the percentage of

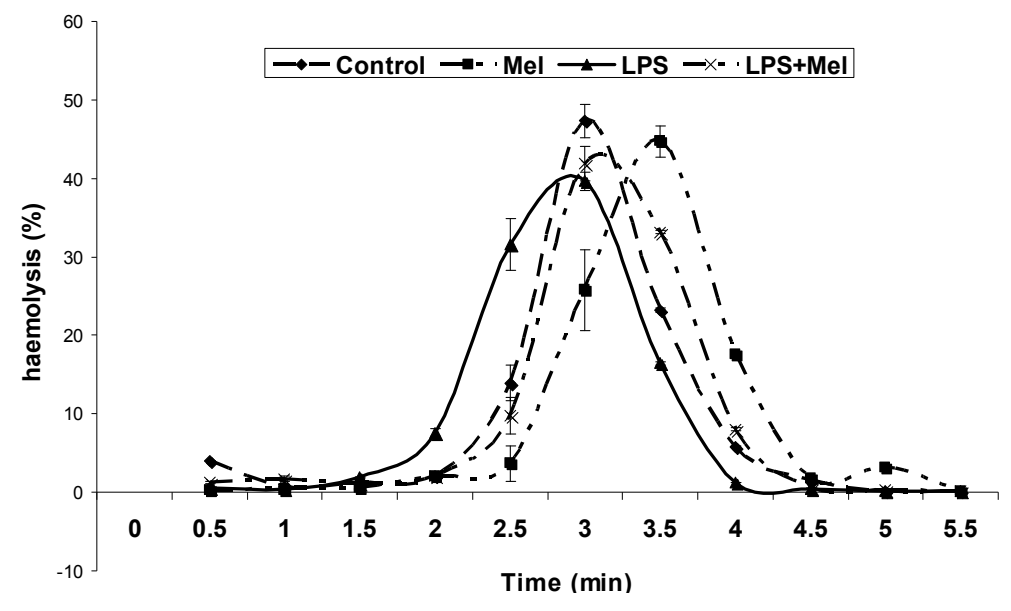

Figure 3. Resistance of erythrocytes to acid (\% haemolysed erythrocytes per minute) from control, melatonin, LPS and LPS+melatonin-treated mice. Results are expressed as mean \pm S.E.M. For abbreviations see Figure 1. 


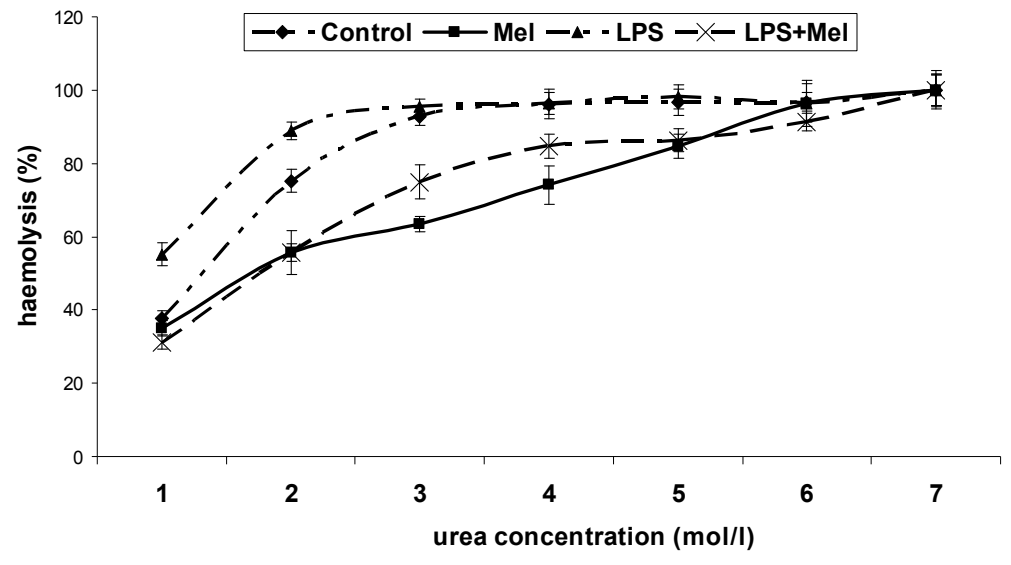

Figure 4. Osmotic resistance of erythrocytes (\% of haemolysed erythrocytes in different concentrations of urea) from control, melatonin, LPS and LPS+melatonin-treated mice. Horizontal axis: urea concentration (1: 0.12, 2: 0.135, 3: 0.15, 4: 0.165, 5: 0.18, 6: 0.195, 7: $0.3 \mathrm{~mol} / \mathrm{l})$. Results are expressed as mean \pm S.E.M. For abbreviations see Figure 1 . haemolysed erythrocytes. Melatonin administration to LPStreated mice increased the acid resistance of erythrocytes.

The osmotic resistance of erythrocytes was investigated next (Fig. 4). Melatonin moved the curve to the right. On the contrary, the percentage of haemolysed erythrocytes with different concentrations of urea was higher after LPS treatment in mice. Melatonin administration to LPS-exposed mice stabilised erythrocyte membranes.

Oxidative stress products such as free radicals have a high reactivity and damage many cell biostructures, especially proteins. Furthermore, we determined concentration of OMP (Table 2) in plasma ( $F=16.98, p=0.000$ for $\mathrm{AD}$ and $\mathrm{F}=12.93, p=0.000$ for $\mathrm{KD}$, respectively), in response to LPS treatment. Melatonin did not affect the OMP concentration. In the LPS group, we observed a 3- to 4-fold elevation in the OMP concentration. Melatonin diminished the effects of LPS. Moreover, melatonin administration did not influence TAC activity. The TAC concentration (Fig. 5) decreased in

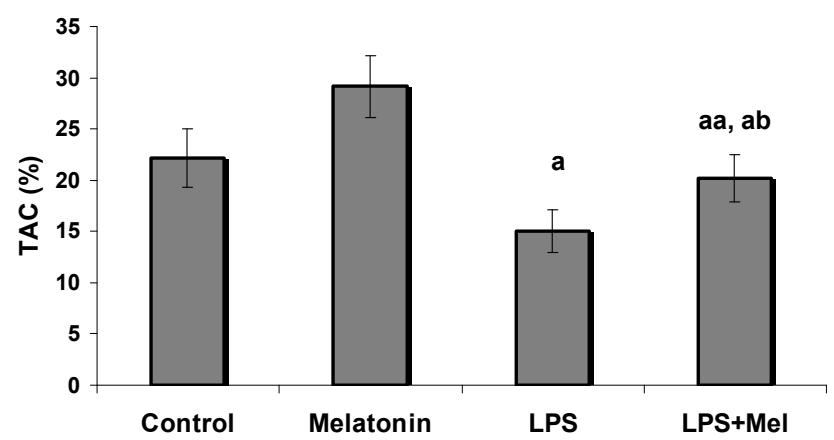

Figure 5. Effect of melatonin (Mel) on the total antioxidant capacity level (\%) in plasma during LPS-induced stress in mice. Results are expressed as mean \pm S.E.M. Differences between experimental groups were analysed by one-way ANOVA and Bonferoni post-hock test; $(n=6)$. Significant differences between groups: ${ }^{a} p<0.05 v s$. Control group, ${ }^{\mathrm{aa}} p<0.05 v$ s. LPS group, ${ }^{\mathrm{ab}} p<0.05 v s$. Mel group. For abbreviations see Figure 1. plasma $(\mathrm{F}=21.05, p=0.000)$ after LPS treatment compared to the control group. Melatonin administration to LPStreated mice augmented the TAC concentration in plasma compared to the LPS group.

The evidence accumulates that pro-inflammatory and oxidative processes are associated with increase in ceruloplasmin concentration in plasma. Ceruloplasmin is a multifunctional protein appearing in acute phase of inflammation. Ceruloplasmin concentration increased in plasma after melatonin treatment (Fig. 6). LPS administration also augmented the ceruloplasmin concentration. Melatonin treatment in LPS-exposed mice lowered the ceruloplasmin concentration in plasma compared to LPS-treated mice.

We observed several interdependences between evoked oxidative stress and antioxidant enzyme activity in response to LPS and melatonin treatment (Table 3). After LPS admin-

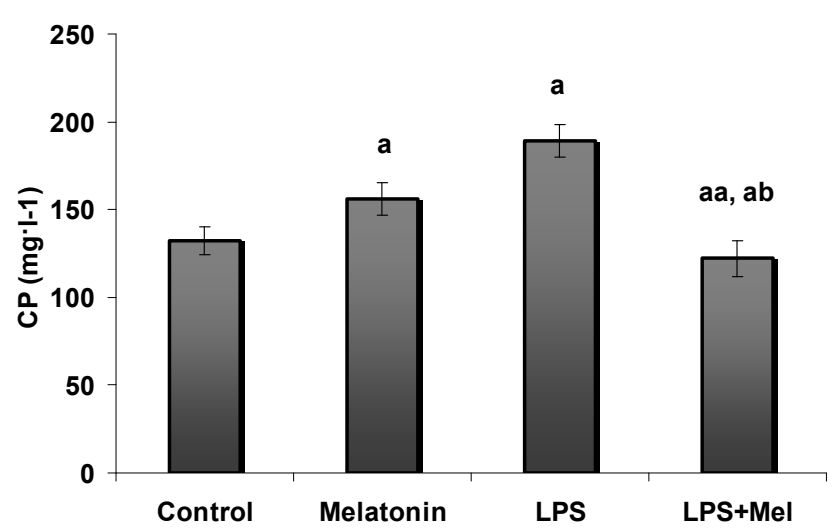

Figure 6. Effect of melatonin on the LPS-induced ceruloplasmin concentration $\left(\mathrm{mg} \cdot \mathrm{l}^{-1}\right)$ in mouse plasma. Results are expressed as mean \pm S.E.M. Differences between experimental groups were analysed by one-way ANOVA and Bonferoni post-hock test; $(n=6)$. Significant differences between groups: ${ }^{\mathrm{a}} p<0.05 v s$. Control group, ${ }^{\mathrm{aa}} p<0.05$ vs. LPS group, ${ }^{\mathrm{ab}} p<0.05 v$ s. Mel group. For abbreviations see Figure 1 . 
Table 2. Effects of melatonin on protein carbonyl derivatives contents in plasma during LPS-induced stress in mice

\begin{tabular}{lcccc}
\hline \multirow{2}{*}{ Protein carbonyl derivatives } & \multicolumn{3}{c}{ Group } \\
\cline { 2 - 5 } & Control & Mel & LPS & LPS+ Mel \\
\hline aldehyde derivative E370·ml & $4.22 \pm 0.56$ & $3.45 \pm 0.23$ & $12.51 \pm 1.16^{\mathrm{a}}$ & $9.34 \pm 1.22^{\text {aa,ab }}$ \\
ketone derivative E420 $\cdot \mathrm{ml}$ & $3.98 \pm 0.22$ & $2.98 \pm 0.09$ & $11.25 \pm 1.13^{\mathrm{a}}$ & $5.16 \pm 0.57^{\text {aa,ab }}$ \\
\hline
\end{tabular}

Results are expressed as mean \pm S.E.M. Differences between experimental groups were analysed by one-way ANOVA and Bonferoni post-hock test; $(n=6)$. Significant differences between groups: ${ }^{\mathrm{a}} p<0.05 v s$. Control group, ${ }^{\text {aa }} p<0.05 v s$. LPS group; ${ }^{\text {ab }} p<0.05 v s$. Mel group. (For abbreviations, see Table 1).

Table 3. Antioxidant enzyme activity in the blood during LPS-induced toxicity and after melatonin (Mel) administration in mice

\begin{tabular}{lcccc}
\hline \multirow{2}{*}{ Parameters } & \multicolumn{3}{c}{ Group } \\
\cline { 2 - 5 } & Control & Mel & LPS & LPS+ Mel \\
\hline SOD $\left(\mathrm{U} \cdot \mathrm{ml}^{-1}\right)$ & $244.56 \pm 45.29$ & $342.17 \pm 29.37$ & $658.88 \pm 58.64^{\mathrm{a}}$ & $422.71 \pm 33.16^{\mathrm{aa}}$ \\
$\mathrm{CAT}\left(\mu \mathrm{mol} \cdot \mathrm{min}^{-1} \cdot \mathrm{l}^{-1}\right)$ & $12.22 \pm 0.31$ & $9.42 \pm 0.39^{\mathrm{a}}$ & $16.11 \pm 1.04^{\mathrm{a}}$ & $13.21 \pm 1.11^{\mathrm{aa}}$ ab \\
GR $\left(\mathrm{nmol} \mathrm{NADPH}{ } \cdot \mathrm{min}^{-1} \cdot \mathrm{ml}^{-1}\right)$ & $88.44 \pm 16.22$ & $99.78 \pm 17.14$ & $156.55 \pm 22.12^{\mathrm{a}}$ & $195.84 \pm 22.16^{\mathrm{ab}}$ \\
GPx $\left(\mathrm{nmol} \mathrm{GSH} \cdot \mathrm{min}^{-1} \cdot \mathrm{ml}^{-1}\right)$ & $56.22 \pm 6.71$ & $78.64 \pm 8.43$ & $118.43 \pm 7.11^{\mathrm{a}}$ & $86.81 \pm 7.24^{\mathrm{aa}}$ \\
\hline
\end{tabular}

Results are expressed as mean \pm S.E.M. Differences between experimental groups were analysed by one-way ANOVA and Bonferoni post-hock test; $(n=6)$. Significant differences between groups: ${ }^{\mathrm{a}} p<0.05 v s$. Control group, ${ }^{\text {aa }} p<0.05 v s$. LPS group; ${ }^{\text {ab }} p<0.05 v s$. Mel group. (For abbreviations, see Table 1).

istration, relationships were observed between ceruloplasmin and conjugated dienes $(\mathrm{r}=0.93, p=0.000, \mathrm{y}=159.5400 \mathrm{x}$ $+1.8546)$, ceruloplasmin and OMP AD $(r=0.89, p=0.001$, $\mathrm{y}=113.2600 \mathrm{x}+1.8114)$ and TAC and ceruloplasmin $(\mathrm{r}=$ $0.90, p=0.000, \mathrm{y}=5.8840 \mathrm{x}+0.1717)$. Melatonin administration in the LPS-treated group showed an interdependency between TAC and ceruloplasmin ( $\mathrm{r}=0.87, p=0.001, \mathrm{y}=$ $4.9035 x+0.1609)$.

\section{Discussion}

In a phase I dose escalation study, melatonin was administered to healthy volunteers at oral doses ranging from 20 to $100 \mathrm{mg}$ per person. Importantly, no adverse reactions other than mild transient drowsiness were reported (Galley et al. 2014). Therefore, the process has already been started to register melatonin as a drug that might be used in various clinical applications. There are several new findings in this study: melatonin 1) diminishes oxidative stress in plasma, 2) retains erythrocytes resistance and 3 ) restores white blood cell counts after acute low dose LPS exposure in mice.

LPS is the predominant inducer of inflammatory responses of Gram-negative bacteria (Sakaguchi and Furusawa 2006). LPS administration has been extensively accepted as an ideal pharmacological research model characterised by increased release of ROS, neutrophil infiltration and the expression of inflammatory cytokines (Blanque et al. 1999; Su et al. 2014). Low-dose LPS disrupts human hematopoiesis including bone marrow progenitor cell expansion and reduced lymphoid potential (Esplin et al. 2011; Liu et al. 2015). Melatonin has been reported to ameliorate the irradiationinduced decline in peripheral WBC (Koc et al. 2002; Shirazi et al. 2013). The effect was attributed to its ROS scavenging properties (Koc et al. 2002). To the best of our knowledge, we are the first to show that melatonin restores WBC in acute low-dose LPS toxicity. Although the beneficial effects of melatonin have been reported in at least five studies (Sewerynek et al. 1996; Fjærli et al. 1999; Yerer et al. 2004; Alamili et al. 2013; Lansink et al. 2016), the LPS doses administered in these studies were much higher, thus mimicking sepsis state. In our study low-dose LPS was administered to develop low grade inflammation and oxidative stress that are typically associated with obesity and diabetes mellitus.

The MDA concentration (the end product of lipid oxidation), as an oxidative stress marker, was elevated in the plasma of LPS-treated animals compared to the control group. MDA is strongly cytotoxic, resulting in a time-dependent haemolysis (Allegra et al. 2002; Tesoriere et al. 2002), an effect that is inhibited by melatonin (Allegra et al. 2003). An important finding of this study is that melatonin stabilises the erythrocyte membrane and permeability, estimated by erythrocyte haemolysis tests. We have shown that the beneficial effects of melatonin on the oxidative damage induced by low-dose LPS are also present in the initial (diene conjugates) stages of the LPO process. Furthermore, the LPS-induced increase in OMP ( $\mathrm{AD}$ and $\mathrm{KD}$ derivatives) can be modified by melatonin as well. 
The supportive effects of melatonin with respect to antioxidant processes in the organism are, to some extent, dependent on the ceruloplasmin concentration. Although ceruloplasmin is synthesised in the liver, $70 \%$ of the total quantity that exists in the organism is found in plasma. Therefore, this protein was used to estimate the inflammatory and oxidative status after LPS treatment. Despite what the systematic name of ceruloplasmin might suggest, i.e. $\mathrm{Fe}(\mathrm{II})$ :oxygen oxidoreductase (ferroxidase I, EC 1.16.3.1), it is a multifunctional protein with broad biological activities (Kamyshnikov 2004).

After LPS administration several interdependencies between ceruloplasmin and conjugated dienes, OMP AD and TAC were observed. After melatonin administration in the LPS-treated group correlation between TAC and ceruloplasmin was demonstrated. Sorenson (1977) formulated the hypothesis that endogenous copper may have protective effect against inflammation. Consequently, an increase in serum concentrations of copper and ceruloplasmin observed in many pathological processes, whether chronic or acute, represents a natural anti-inflammatory response (Sorenson 1977; Goldstein et al. 1982). Consequently, the reduction in ceruloplasmin concentrations seen in response to melatonin may reflect an overall decrease in inflammatory and oxidative status.

Free radicals can be defined as molecules or molecular fragments containing one or more unpaired electrons in atomic or molecular orbitals. The addition of one electron to dioxygen forms the superoxide anion radical $\left(\mathrm{O}_{2}{ }^{--}\right)$. Superoxide anion, arising either through metabolic processes or following oxygen "activation" by physical irradiation, is considered the "primary" ROS, and can further interact with other molecules to generate "secondary" ROS, either directly or prevalently through enzyme- or metal-catalysed processes (Valko et al. 2007). Various pathways of ROS formation under different agents have been previously examined. The inductors of inflammatory processes and oxidative stress are toxic hydroxyl radicals. These radicals, released during inflammation, can activate neutrophils and macrophages. These cells release superoxide anion radicals due to the activation of membrane enzyme NADPH-oxidase. The "oxygen burst" caused by the high activity of this enzyme to generate free radicals is the part of the protective mechanism against invading microbial pathogens (Halliwell 2007; Wang and Quinn 2010). Antioxidant enzymes (superoxide dismutase (SOD), catalase (CAT), glutathione peroxidase (GPx), glutathione reductase (GR), ceruloplasmin (CP), and the reduced and oxidised glutathione ratio) play an important role in protecting the cell from the harmful effects of ROS; in the our study, this effect was strongly modulated by melatonin. Melatonin is known to be a powerful antioxidant (Sönmez et al. 2012). It exhibits direct antioxidant properties, acting as a scavenger of free radicals, indirectly enhances the activity of anti-oxidative enzymes (SOD, CAT and GPx) and can stabilise their concentrations (Watson 2012).

The inflammatory response to LPS was not assessed in this study. However, these measurements have been well-described in animals and humans, and our data are consistent with previous findings (Baker at al. 2014). Therefore, we are confident that our acute LPS dose evoked the typical inflammatory reaction and consequent oxidative stress. Furthermore, we did not measure plasma melatonin concentration in experimental animals.

\section{Conclusion}

Low-dose LPS administration in mice results in WBC depletion, erythrocyte cell membrane impairment and oxidative stress in plasma characterised by lipid and protein oxidative processes, decreased antioxidative defence and augmented ceruloplasmin concentrations. Melatonin treatment provided to low-dose LPS-exposed animals restored the WBC count, ameliorated erythrocyte membrane damage and decreased indicators of overall oxidative stress in plasma.

\section{Conflict of interest. None.}

Acknowledgement. The study was supported by Pomeranian University of Slupsk, National State University of Chernihiv and Medical University of Gdansk.

\section{References}

Alamili M, Klein M, Lykkesfeldt J, Rosenberg J, Gögenur I (2013): Circadian variation in the response to experimental endotoxemia and modulatory effects of exogenous melatonin. Chronobiol. Int. 30, 1174-1180 https://doi.org/10.3109/07420528.2013.808653

Al-Attas OS, Al-Daghri NM, Al-Rubeaan K, da Silva NF, Sabico SL, Kumar S, McTernan PG, Harte AL (2009): Changes in endotoxin levels in T2DM subjects on anti-diabetic therapies. Cardiovasc. Diabetol. 8, 20

https://doi.org/10.1186/1475-2840-8-20

Allegra M, Gentile C, Tesoriere L, Livrea MA (2002): Protective effect of melatonin against cytotoxic actions of malondialdehyde: an in vitro study on human erythrocytes. J. Pineal Res. 32, 187-193 https://doi.org/10.1034/j.1600-079x.2002.10852.x

Annane D, Bellissant E, Cavaillon JM (2005): Septic shock. Lancet $365,63-78$ https://doi.org/10.1016/S0140-6736(04)17667-8

Baker B, Maitra U, Geng S, Li L (2014): Molecular and cellular mechanisms responsible for cellular stress and low-grade inflammation induced by a super-low dose of endotoxin. J. Biol. Chem. 289, 16262-16269 https://doi.org/10.1074/jbc.M114.569210

Blanque R, Meakin C, Millet S, Gardner CR (1999): Dual mechanisms of action of interferon- $\gamma$ in potentiating responses to 
LPS in mice IL1, TNFa and IL6 production in serum and hypothermia. Gen. Pharmacol. 32, 453-461 https://doi.org/10.1016/S0306-3623(98)00217-1

Bonnefont-Rousselot D, Collin F (2010): Melatonin: action as antioxidant and potential applications in human disease and aging. Toxicology 278, 55-67 https://doi.org/10.1016/j.tox.2010.04.008

Bradford MM (2010): A rapid and sensitive method for the quantitation of microgram quantities of protein utilizing the principle of protein-dye binding. Anal. Biochem. 72, 248-254 https://doi.org/10.1016/0003-2697(76)90527-3

Cadenas S, Cadenas AM (2002): Fighting the stranger-antioxidant protection against endotoxin toxicity Toxicology 180, 45-63 https://doi.org/10.1016/S0300-483X(02)00381-5

Cani PD, Bibiloni R, Knauf C, Waget A, Neyrinck AM, Delzenne NM, Burcelin R (2008): Changes in gut microbiota control metabolic endotoxemia-induced inflammation in high-fat dietinduced obesity and diabetes in mice. Diabetes 57, 1470-1481 https://doi.org/10.2337/db07-1403

Creely SJ, McTernan PG, Kusminski CM, Fisher fM, Da Silva NF, Khanolkar M, Evans M, Harte AL, Kumar S (2007): Lipopolysaccharide activates an innate immune system response in human adipose tissue in obesity and type 2 diabetes. Am. J. Physiol. Endocrinol. Metab. 292, E740-747 https://doi.org/10.1152/ajpendo.00302.2006

Dauphinee SM, Karsan A (2006): Lipopolysaccharide signaling in endothelial cells. Laboratory Investigation 86, 9-22 https://doi.org/10.1038/labinvest.3700366

Dubinina EE, Burmistrov SO, Khodov DA, Porotov IG (1995): Oxidative modification of human serum proteins. A method of determining it. Vopr. Med. Khim. 41, 24-26

Escames G, Guerrero JM, Reiter RJ, Garcya JJ, Munoz Hoyos A, Ortiz GG, Oh CS (1997): Melatonin and vitamin E limit nitric oxide-induced lipid peroxidation in rat brain homogenates. Neurosci. Lett. 230, 147-150 https://doi.org/10.1016/S0304-3940(97)00498-9

Esplin BL, Shimazu T, Welner RS, Garrett KP, Nie L, Zhang Q, Humphrey MB, Yang Q, Borghesi LA, Kincade PW (2011): Chronic exposure to a TLR ligand injures hematopoietic stem cells. J. Immunol. 186, 5367-5375 https://doi.org/10.4049/jimmunol.1003438

Faist E, Angele K., Zedler S (1999): Immunoregulation in shock, trauma and sepsis. In: The Immune Response in Critical Illness. (Ed. Marshall JC, Cohen J), pp. 312-334, Springer Verlag, New York

Fjærli O, Lund T, Østerud B (1999): The effect of melatonin on cellular activation processes in human blood. J. Pineal Res. 26, 50-55 https://doi.org/10.1111/j.1600-079X.1999.tb00566.x

Galaktionova LP, Molchanov AV, Elchaninova SA, Varshavskiy BY (1998): Lipid peroxidation in patients with gastric and duodenal ulcers. Klin. Lab. Diag. 6, 10-14

Galley HF, Lowes DA, Allen L, Cameron G, Aucott LS, Webster NR (2014): Melatonin as a potential therapy for sepsis: a phase I dose escalation study and an ex vivo whole blood model under conditions of sepsis. J. Pineal Res. 56, 427-438 https://doi.org/10.1111/jpi.12134

Glatzle D, Vuilleumier JP, Weber F, Decker K (1974): Glutathione reductase test with whole blood, a convenient procedure for the assessment of the riboflavin status in human. Experientia 30, 665-666 https://doi.org/10.1007/BF01921531

Goldstein IM, Kaplan HB, Edelson HS, Weissmann G (1982): Ceruloplasmin: an acute phase reactant that scavenges oxygenderived free radicals. Ann. N. Y. Acad. Sci. 389, 368-379 https://doi.org/10.1111/j.1749-6632.1982.tb22150.x

Halliwell B (2007): Biochemistry of Oxidative Stress. Biochem Soc Trans. 35, 1147-1150 https://doi.org/10.1042/BST0351147

Hu W, Deng C, Ma Z, Wang D, Fan C, Li T, Di S, Gong B, Reiter RJ, Yang Y (2017): Utilizing melatonin to combat bacterial infections and septic injury. Br. J. Pharmacol. 174, 754-768 https://doi.org/10.1111/bph.13751

Kamyshnikov VS (2004): Reference Book on Clinic and Biochemical Researches and Laboratory Diagnostics. MEDpress-inform., Moscow

Koc M, Buyukokuroglu ME, Taysi S (2002): The effect of melatonin on peripheral blood cells during total body irradiation in rats. Biol. Pharm. Bull. 25, 656-657 https://doi.org/10.1248/bpb.25.656

Koroliuk MA, Ivanova LI, Majorova IG, Tokarev VE (1988): A method of determining catalase activity. Lab. Delo 1, 16-19

Kostiuk VA, Potapovich AI, Kovaleva ZhV (1990): A simple and sensitive method of determination of superoxide dismutase activity based on the reaction of quercetin oxidation. Vopr. Med. Khim. 36, 88-91

Kurhaluk N, Sliuta A, Kyriienko S, Winklewski PJ (2017): Melatonin restores white blood cell count, diminishes glycated haemoglobin level and prevents liver, kidney and muscle oxidative stress in mice exposed to acute ethanol intoxication. Alcohol Alcohol. 52, 521-528 https://doi.org/10.1093/alcalc/agx045

Lansink, MO, Görlinger K, Hartmann M, De Groot H, EffenbergerNeidnicht K (2016): Melatonin does not affect disseminated intravascular coagulation but diminishes decreases in platelet count during subacute endotoxaemia in rats. Thromb. Res. 139, 38-43 https://doi.org/10.1016/j.thromres.2015.10.025

Lassenius MI, Pietiläinen KH, Kaartinen K, Pussinen PJ, Syrjänen J, Forsblom C, Pörsti I, Rissanen A, Kaprio J, Mustonen J, et al. (2011): Bacterial endotoxin activity in human serum is associated with dyslipidemia, insulin resistance, obesity, and chronic inflammation. Diabetes Care 34, 1809-1815

https://doi.org/10.2337/dc10-2197

Levine RL, Garland D, Oliver CN, Amici A, Climent I, Lenz AG, Ahn BW, Shaltiel S, Stadtman ER (1990): Determination of carbonyl content in oxidatively modified proteins. Methods Enzymol. 186, 465-478 https://doi.org/10.1016/0076-6879(90)86141-H

Liu A, Wang Y, Ding Y, Baez I, Payne KJ, Borghesi L (2015): Cutting edge: hematopoietic stem cell expansion and common lymphoid progenitor depletion require hematopoietic-derived, cell-autonomous TLR4 in a model of chronic endotoxin. J. Immunol. 195, 2524-2528 https://doi.org/10.4049/jimmunol.1501231

Melchiorri D, Reiter RJ, Sewerynek E, Chen LD, Nisticot G (1995): Melatonin reduces kainate-induced lipid peroxidation in homogenates of different brain regions. FASEB J. 9, 1205-1210 
https://doi.org/10.1096/fasebj.9.12.7672513

Moin VM (1986): A simple and specific method for determining glutathione peroxidase activity in erythrocytes. Lab. Delo 12, 724-727

Sakaguchi S, Furusawa S (2006): Oxidative stress and septic shock: metabolic aspects of oxygen-derived free radicals generated in the liver during endotoxemia. FEMS. Immunol. Med. Microbiol. 47, 167-177 https://doi.org/10.1111/j.1574-695X.2006.00072.x

Saravanan KS, Sindhu KM, Mohankumar KP (2007): Melatonin protects against rotenone-induced oxidative stress in a hemiparkinsonian rat model. J. Pineal Res. 42, 247-253 https://doi.org/10.1111/j.1600-079X.2006.00412.x

Sewerynek E, Melchiorri D, Russel CL, Reiter J (1995): Melatonin reduces both basal and bacterial lipopolysaccharideinduced lipid peroxidation in vitro. Free Radic. Biol. Med. 19, 903-909 https://doi.org/10.1016/0891-5849(95)00101-3

Sewerynek E, Ortiz GG, Reiter RJ, Pablos MI, Melchiorri D, Daniels WMU (1996): Lipopolysaccharide-induced DNA damage is greatly reduced in rats treated with the pineal hormone melatonin. Mol. Cell. Endocrinol. 117, 183-188 https://doi.org/10.1016/0303-7207(95)03742-X

Shirazi A, Mihandoost E, Mohseni M, Ghazi-Khansari M, Rabie Mahdavi S (2013): Radio-protective effects of melatonin against irradiation-induced oxidative damage in rat peripheral blood. Phys. Med. 29, 65-74 https://doi.org/10.1016/j.ejmp.2011.11.007

Sönmez MF, Narin F, Akkuş D, Türkmen AB (2012): Melatonin and vitamin $\mathrm{C}$ ameliorate alcohol-induced oxidative stress and eNOS expression in rat kidney. Ren. Fail. 34, 480-486 https://doi.org/10.3109/0886022X.2011.649678

Sorenson JRJ (1977): Evaluation of copper-complexes as potential anti-arthritic drugs. J. Pharm. Pharmacol. 29, 450-452 https://doi.org/10.1111/j.2042-7158.1977.tb11367.x

Su ZQ, Mo ZZ, Liao JB, Feng XX, Liang YZ, Zhang X, Liu YH, Chen XY, Chen ZW, Su ZR, Lai XP (2014): Usnic acid protects LPS-induced acute lung injury in mice through attenuating inflammatory responses and oxidative stress. Int. Immunopharmacol. 22, 371-378 https://doi.org/10.1016/j.intimp.2014.06.043
Terskov IA, Gitelson II (1957): Method of chemical (acid) erythrogramma. Biofyzika 2, 59-266

Tesoriere L, D'Arpa D, Butera D, Pintaudi AM, Allegra M, Livrea MA (2002): Exposure to malondialdehyde induces an early redox unbalance preceding membrane toxicity in human erythrocytes. Free Radic. Res. 36, 89-97 https://doi.org/10.1080/10715760210163

Valko M, Leibfritz D, Moncol J, Cronin MT, Mazur M, Telser J (2007): Free radicals and antioxidants in normal physiological functions and human disease. Int. J. Biochem. Cell Biol. 39, $44-84$ https://doi.org/10.1016/j.biocel.2006.07.001

von Gall C, Stehle JH, Weaver DR (2002): Mammalian melatonin receptors: molecular biology and signal transduction. Cell Tissue Res. 309, 151-162 https://doi.org/10.1007/s00441-002-0581-4

Wang X, Quinn PJ (2010): Lipopolysaccharide: Biosynthetic pathway and structure modification. Prog. Lipid Res. 49, 97-107 https://doi.org/10.1016/j.plipres.2009.06.002

Watson RR (2012): Metatonin in the Promotion and Health. Second edition. CRC Press, Taylor Francis Group Yang Yi, Zhang R, Xia F, Zou T, Huang A, Xiong S, Zhang J (2013): LPS converts Gr-1+CD115+ myeloid-derived suppressor cells from M2 to M1 via P38 MAPK. Exp. Cell Res. 2013, 1774-1783

Wichmann MW, Inthorn D, Aandress H-J, Schildberg FW (2000): Incidence and mortality of severe sepsis in surgical intensive care patients: the influence of patient gender on disease process and outcome. Int. Care Med. 26, 167-172 https://doi.org/10.1007/s001340050041

Yerer MB, Yapislar H, Aydogan S, Yalcin O, Baskurt O (2004): Lipid peroxidation and deformability of red blood cells in experimental sepsis in rats: The protective effects of melatonin. Clin. Hemorheol. Microcirc. 30, 77-82

Yu WK, Li WQ, Li N, Li JS (2003): Influence of acute hyperglycemia in human sepsis on inflammatory cytokine and counterregulatory hormone concentrations. World J. Gastroenterol. 9, 1824-1827 https://doi.org/10.3748/wjg.v9.i8.1824

Received: January 13, 2018

Final version accepted: March 16, 2018 